\title{
Morphological aspects in the ontogeny of Salminus hilarii Valenciennes, 1850 (Ostaryophysi: Characidae)
}

\author{
G. A. Villares Junior ${ }^{*}$ and R. Goitein ${ }^{a}$

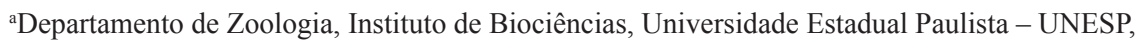 \\ Av. 24-A, 1515, CP 199, CEP 13506-900, Rio Claro, SP, Brazil \\ *e-mail: villaresjunior@hotmail.com
}

Received: March 16, 2015 - Accepted: August 18, 2015 - Distributed: November 30, 2016

(With 3 figures)

\begin{abstract}
This study compared various morphological characteristics of S. hilarii, in order to verify possible variations over the life of the fish. It was used individuals collected from the Tietê river basin (sub-basins of Sorocaba, Jacaré Pepira and Corumbataí rivers) and from the Rio Grande basin (sub-basins of Pardo and Mogi Guaçu rivers). For the analysis we used 15 relative values of morphological attributes. Measures of $S$. hilarii were taken from samples with a range of size ranging between $49-430 \mathrm{~mm}$ standard length. The relative values were first analyzed by an array of Principal Component Analysis of correlation (PCA). Subsequently the most important attributes of PCA were correlated with standard length, using the Pearson correlation coefficient. The PCA revealed eight most important characteristics, and six showed a significant correlation with standard lengths (relative height, depth ratio, relative area of caudal fin, relative head length, eye diameter relative height and relative mouth height), indicating common variations along the fish's growth besides indicating an adaptation to the conditions of the environment it occupies. On the other hand some characteristics have not changed, maintaining typical morphological patterns of fish that occupy the middle water and piscivorous predators.
\end{abstract}

Keywords: tabarana, development, adaptation, traits.

\section{Aspectos Morfológicos na ontogenia de Salminus hilarii Valenciennes, 1850 (Ostaryophysi: Characidae)}

\section{Resumo}

Este trabalho comparou várias características morfológicas de $S$. hilarii, com a finalidade de verificar possíveis variações ao longo da vida do peixe. Foram utilizados indivíduos coletados nas bacias dos rios Tietê (sub-bacias dos rios Sorocaba, Jacaré Pepira e Corumbataí) e da bacia do rio Grande (sub-bacias dos rios Mogi Guaçu e Pardo). Para as análises foram utilizados 15 valores relativos de atributos morfológicos. As medidas de $S$. hilarii foram tomadas a partir de exemplares com uma amplitude de tamanho variando entre 49 a $430 \mathrm{~mm}$ de comprimento padrão. Os valores relativos foram analisados primeiramente por uma Análise de Componentes Principais (PCA). Posteriormente os atributos mais importantes da PCA foram correlacionados com o comprimento padrão, utilizando o coeficiente de correlação de Pearson. A análise de componentes principais revelou oito características mais importantes sendo que seis mostraram correlação significativa com os comprimentos padrão (altura relativa, razão de profundidade, área relativa da nadadeira caudal, comprimento relativo da cabeça, diâmetro relativo do olho, altura relativa da boca, indicando variações comuns ao longo do crescimento do peixe, além de, indicar uma adequação para as condições dos ambientes que ocupa. Por outro lado, outras características não mudaram, mantendo padrões morfológicos típicos de peixes que ocupam a meia água e de predadores piscívoros.

Palavras-chave: tabarana, desenvolvimento, adaptação, características.

\section{Introduction}

Included within the Characiformes order, Salminus hilarii Valenciennes, 1850 is similar to $S$. brasiliensis (Cuvier, 1816), differing by the white and silver color besides being smaller in size. It is a typical predator species, preferably found in running waters of medium and small rivers. It is considered as rheophilic fish with the reproductive period between late spring and summer (Agostinho et al., 2004; Andrade et al., 2004; Godoy, 1975; 
Honji, 2007; Honji et al., 2011; Takahashi, 2006; Villares Junior et al., 2007; Villares Júnior, 2014). Currently, the species is threatened in the region of the Upper Paraná River Basin by industrial and domestic pollution and dam construction (Honji, 2007; Graça and Pavanelli, 2007).

Morphologically, S. hilarii has as a typical configuration of predatory fish with elongated fusiform body, a terminal type mouth with a wide opening and the jaw slightly protruding before in relation to the pre-jaw. The teeth are sharp and facing the inside of the mouth (Godoy, 1975), relating to the evasive preys (Aleev, 1969; Teixeira and Bennemann, 2007).

The study of morphology may reflect integration between environmental influences with the organism behavior, life history and feeding habitats. In fish, studies of this nature are conducted with adult fish, generally focusing on the existence of correlations between morphological and ecological variables (Chao and Musick, 1977; Singer, 1985). Besides, examining how functional morphology change during the ontogeny is another interesting research question that is rarely considered (Mullaney Júnior and Gale, 1996).

There is a high diversity of forms of embryos, larvae and juvenile fish (Balon et al., 1986), but the ecological correlations have not been fully clarified. Research on intra-specific morphological variations in neotropical fish stocks are scarce (Shibatta and Garavello, 1993). The study of the functional anatomy related to fish nourishment can bring basic information about the occupation of ecological niches and their adaptations to this occupation.
As little is known about morphological changes in ontogeny of neotropical freshwater fish, this study aims to evaluate how morphological traits of S. hilarii changes during its relating them to swimming and feeding.

\section{Material and Methods}

\subsection{Morphological attributes}

For this study it was analyzed 58 individuals of Salminus hilarii originated from the upper Paraná river basin rivers, being 42 collected in the Tietê rivers basins (sub-basins of the Sorocaba, Jacaré Pepira and Corumbataí rivers) and 16 in the Rio Grande basin (sub-basins of Mogi Guaçu and Pardo rivers). The measurements were taken from samples with a size ranging from 49 to $430 \mathrm{~mm}$ (standard length).

It was used 15 relative values of the morphological attributes based on, Gatz Júnior (1979a), Motta et al. (1995), Pauly, (1989), Webb (1984) and Carneiro (2003) (Table 1):

\subsection{Data analysis}

It was first performed a multivariate analysis using a Principal Component Analysis (PCA) using the matrix of correlation of the morphological attribute in order describe of the principal sources of morphological variations.

Subsequently the most important attributes (attributes with the higher loads) of the first two axes of the PCA were correlated with standard length using Pearson correlation coefficient considering $\alpha=0.05$. For the statistical test it was used the PAST 2:15 software (Hammer et al., 2001).

Table 1. Description of the 15 relative values calculated to Salminus hilarii with their respective formulas and definitions.

\begin{tabular}{|c|c|c|}
\hline Morphological attributes & Formula & Definition \\
\hline Flatness index & $\mathrm{IF}=$ Hmáx/Lmáx & Maximum height divided by the maximum width. \\
\hline Relative height & $\mathrm{RH}=\mathrm{Hmáx} / \mathrm{SL}$ & Maximum height divided by the standard length. \\
\hline Depth ratio & $\mathrm{DR}=\mathrm{SL} / \mathrm{Hmáx}$ & Standard length divided by the maximum body height. \\
\hline $\begin{array}{l}\text { Relative caudal peduncle } \\
\text { length }\end{array}$ & $\mathrm{RCPL})=\mathrm{CPC} / \mathrm{SL}$ & Caudal peduncle length divided by the standard length. \\
\hline $\begin{array}{l}\text { Relative caudal peduncle } \\
\text { height }\end{array}$ & $\mathrm{RCPH}=\mathrm{PPC} / \mathrm{Hmáx}$ & $\begin{array}{l}\text { Caudal peduncle height divided by the maximum } \\
\text { height. }\end{array}$ \\
\hline $\begin{array}{l}\text { Caudal peduncle } \\
\text { compression index }\end{array}$ & $\mathrm{CPCI}=\mathrm{HPC} / \mathrm{LPC}$ & $\begin{array}{l}\text { Caudal peduncle height divided by the caudal peduncle } \\
\text { width. }\end{array}$ \\
\hline Relative area of caudal fin & $\mathrm{RACF}=\mathrm{SC} / \mathrm{SLxHmáx}$ & $\begin{array}{l}\text { Area of the caudal fin divided by the product of the } \\
\text { standard length and the maximum height. }\end{array}$ \\
\hline Caudal fin aspect ratio & $\begin{array}{l}\text { Ac: calculated by the } \\
\text { expression: } \mathrm{A}=\mathrm{HC}^{2} / \mathrm{S}\end{array}$ & $\begin{array}{l}\mathrm{Ac}=\text { aspect ratio, } \\
\mathrm{HC}=\text { caudal fin height } \\
\mathrm{S}=\text { area of caudal fin. }\end{array}$ \\
\hline Pectoral fin aspect ratio & $\mathrm{Ap}=\mathrm{CNP} / \mathrm{LNP}$ & Length of the pectoral fin divided by the width. \\
\hline Relative area of pectoral fin & $\mathrm{RAPF}=\mathrm{SP} / \mathrm{SLxHmáx}$ & $\begin{array}{l}\text { Area of the pectoral fin divided by the product of the } \\
\text { standard length and the maximum height. }\end{array}$ \\
\hline Relative mouth width & $(\mathrm{RMW})=(\mathrm{LB} / \mathrm{SL})$ & Open mouth width divided by the standard length. \\
\hline Relative mouth height & $\mathrm{RMH}=\mathrm{HB} / \mathrm{SL}$ & Open mouth height divided by the standard length. \\
\hline Relative jaw length & $\mathrm{RJL}=\mathrm{CM} / \mathrm{SL}$ & Jaw length divided by the standard length. \\
\hline Relative head length & $\mathrm{RHL}=\mathrm{Ccb} / \mathrm{SL}$ & Head length divided by the standard length. \\
\hline Relative eye diameter & $\mathrm{RED}=\mathrm{DO} / \mathrm{SL}$ & eye diameter divided by the standard length. \\
\hline
\end{tabular}




\section{Results}

The first component (PC1) explained $27.73 \%$ of the variance, with the relative height having the highest negative loading and depth ratio, relative area of caudal fin, relative mouth height and relative eye diameter the largest positive loading. The second component (PC2) explained 16.42\% thus adding $44.15 \%$ of explained variance. In this axis the principal components were the relative caudal peduncle height with the highest negative loading and the relative head length and relative jaw length with the largest positive loading, (Figure 1, Table 2).

The Pearson correlation coefficient (Figure 2) showed significant correlations among standard length and six of the most attributes highlighted in the PCA (relative height, depth ratio, relative area of caudal fin, relative head length, eye diameter relative height and relative mouth height), indicating that several morphological attributes showed allometric variations along the fish growth. Although highlighted in the PCA, the relative caudal peduncle height and the relative length of the jaw showed no significant correlation with the length, indicating no signs of allometry.

\section{Discussion}

The fish fins allow a sudden interaction with water, revealing a strong adaptability to the environment (Breda et al., 2005; Videler, 1993), determined by the type of swimming required for optimal survival and ability to explore diverse niches (Breda et al., 2005; Videler, 1993; Jobling, 1995). Caudal fins with large area and low-aspect ratio values indicate that fish produce quick starts (impulse) (Aleev, 1969; Sambilay Júnior, 1990;

Table 2. Loading values between the 15 morphological attributes for the two principal axis of PCA calculated for the length classes of Salminushilarii.

\begin{tabular}{lcc}
\hline \multicolumn{1}{c}{ Morphological attributes } & PC1 & PC2 \\
\hline Flatness index & -0.29057 & 0.09248 \\
Relative height & -0.36849 & 0.35678 \\
Depth ratio & 0.36374 & 0.34156 \\
Relative caudal peduncle & -0.04779 & 0.13659 \\
length & & \\
Relative caudal peduncle & 0.21703 & -0.42959 \\
height & & \\
Caudal peduncle compression & -0.16781 & -0.07267 \\
index & & \\
Relative area of caudal fin & 0.34803 & 0.1746 \\
Caudal fin aspect ratio & 0.1098 & -0.30463 \\
Pectoral fin aspect ratio & 0.30307 & 0.3801 \\
Relative area of pectoral fin & 0.18304 & 0.17605 \\
Relative mouth width & 0.33196 & 0.12295 \\
Relative mouth height & 0.18635 & 0.4304 \\
Relative jaw length & 0.34572 & 0.10878 \\
Relative head length & 0.0497 & 0.07136 \\
Relative eye diameter & 0.2265 & 0.15151 \\
\hline
\end{tabular}

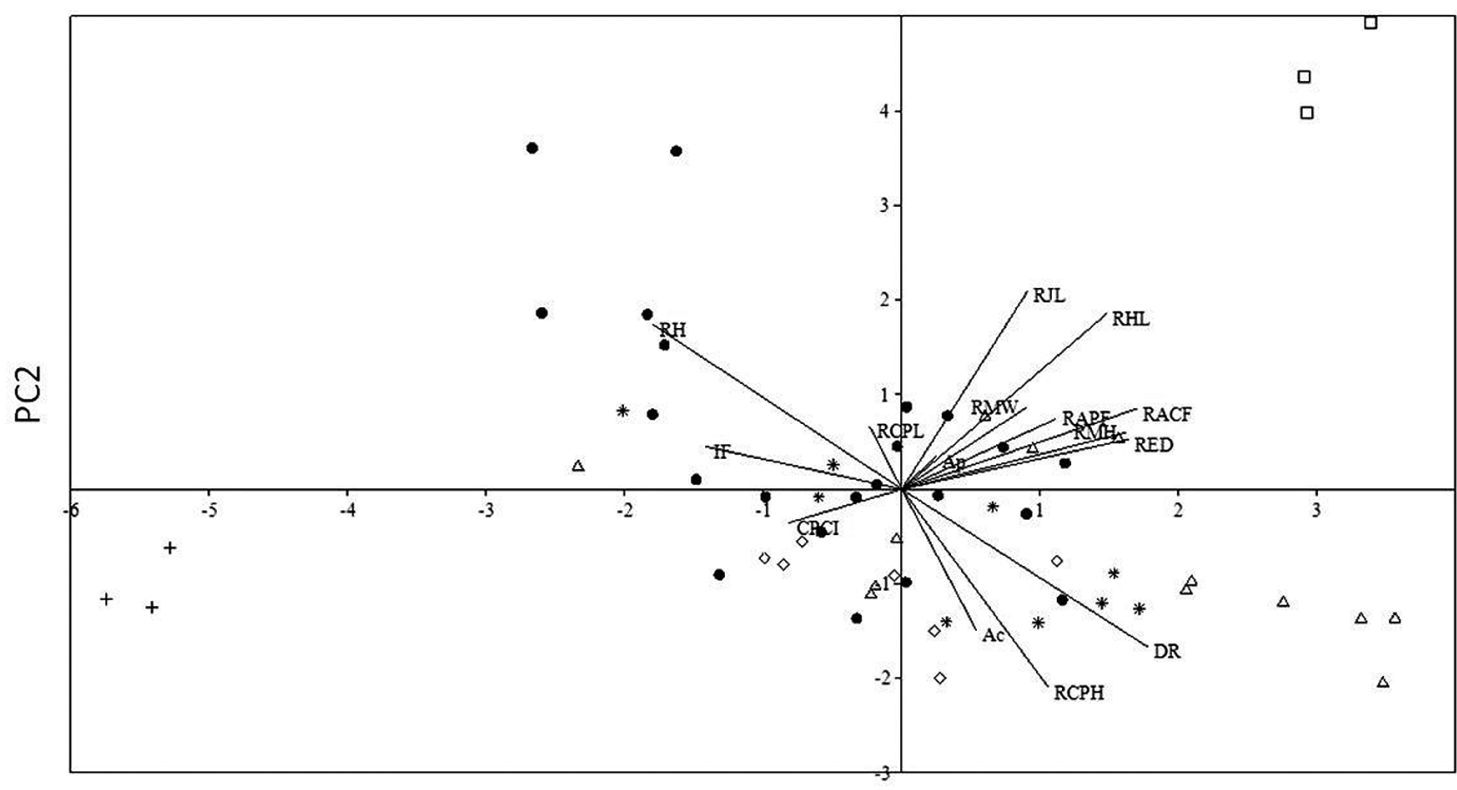

PC1

Figure 1. Projection of the two first principal components with the vectors of the 15 morphological attributes for the length class of Salminus hilarii. IF, flatness index; RH, relative height; DR, depth ratio; RCPL, relative caudal peduncle length; RCPH, relative caudal peduncle height; CPCI, caudal peduncle compression index; RACF, relative area of caudal; Ac, caudal fin aspect ratio; Ap, pectoral fin aspect ratio; RAPF, relative area of pectoral fin; RMW, relative mouth width; RMH, relative mouth height; RJL, relative jaw length; RHL, relative head length; RED, relative eye diameter. The symbols represent the following size classes: squares $=50$ - 100; triangles $=100+150$; diamonds $=150 \vdash 200 ;$ stars $=200 \vdash 250$; circles $=250$ - 300 ; cross $=400 \vdash 450$. 

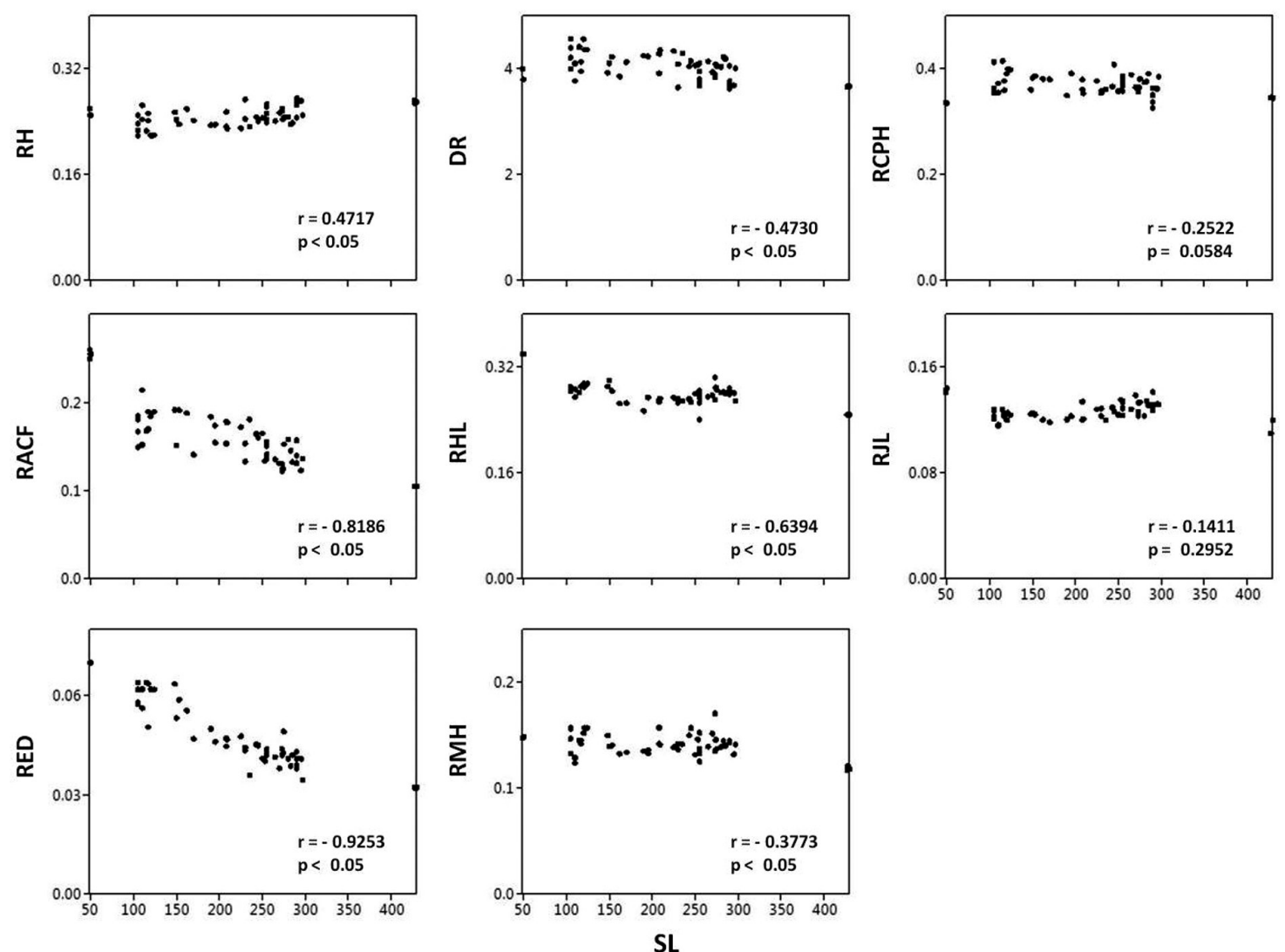

Figure 2. Scatter plot of the principal morphological attributes in relation to their standard lengths. $r=$ Pearson correlation coefficient; $\mathrm{p}=$ probabilities.

Webb and Weihs, 1986) showing better performance in heterogeneous sites (Gosline, 1971) and more ability to perform maneuvers (Jobling, 1995; Videler, 1993; Casatti and Castro, 2006). In S. hilarii a gradual reduction was observed in the caudal fin relative areas. With a smaller fin area, the fish can maintain a higher frequency of beats of this fin, allowing higher speed and lower energy consumption resulting from the drag force of the rapids. On the other hand the aspect ratio of the caudal fin showed no difference, showing that differentiation does not occur in the form of caudal fin (Figure 3) in the development of this species and potentially in its function. The caudal fin characteristics observed for $S$. hilarii give an indication for better efficiency for locomotion, indicating the swimming behavior with continuous swimming and occupying the middle water.

The fish body shape can be interpreted as the result of evolutionary adaptations to environmental pressures. Thus the resistance that water has on the body should be known due to the high correlation it presents to hydrodynamic aspects (Winston, 1995). The relationship between the shape of the body and the swimming performance influences the ability the fish has to keep itself in the water column, the acquisition of food and avoid predators (Videler, 1993). Fish with higher bodies have better ability to produce lateral movements (Aleev, 1969; Gatz Júnior, 1979a, b) besides affecting the maintenance of the fish speed (Webb and Weihs, 1986), once the value that most favors the maintenance of fish speed is the intermediate (Pauly, 1989). Fish with higher bodies have higher performance in habitats where the maneuvers are more important, as in full of obstacles locations (Breda et al., 2005). Fish like these are more efficient in start and maneuvers in relation to fish with more elongated bodies, showing better performance in structurally complex environments (Neves and Monteiro, 2003). This increase in height may indicate an ability to overcome strong rapids and obstacles such as rocks and waterfalls besides compensating and/or minimizing the prey escape strategies. The allometric increase of body height was compensated in proportion to the values of flatness index, maintaining a standard cross-section of the fusiform type. The fusiform form is characteristic by having the oval cross section and maximum height of the body located approximately one third of its previous total length and relatively thin, elongated caudal peduncle (Lagler et al., 1977), this being the most common form of fish with regular and sustained swimming (Keast and Webb, 1966) and related to fish swimming in waters with stronger current (Gatz Júnior, 1979a, b), concomitant factors to the lifestyle of $S$. hilarii. A higher body height added to a smaller area of the caudal fin and consequent low value of the caudal fin aspect ratio, enables the largest 
$\mathbf{a}$
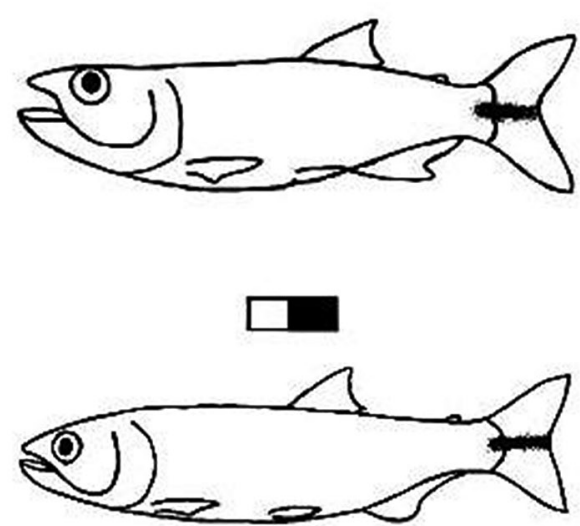

ㅁ.

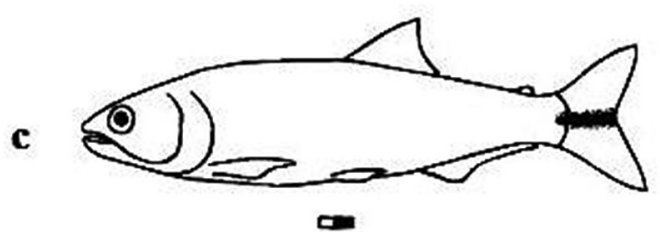

d
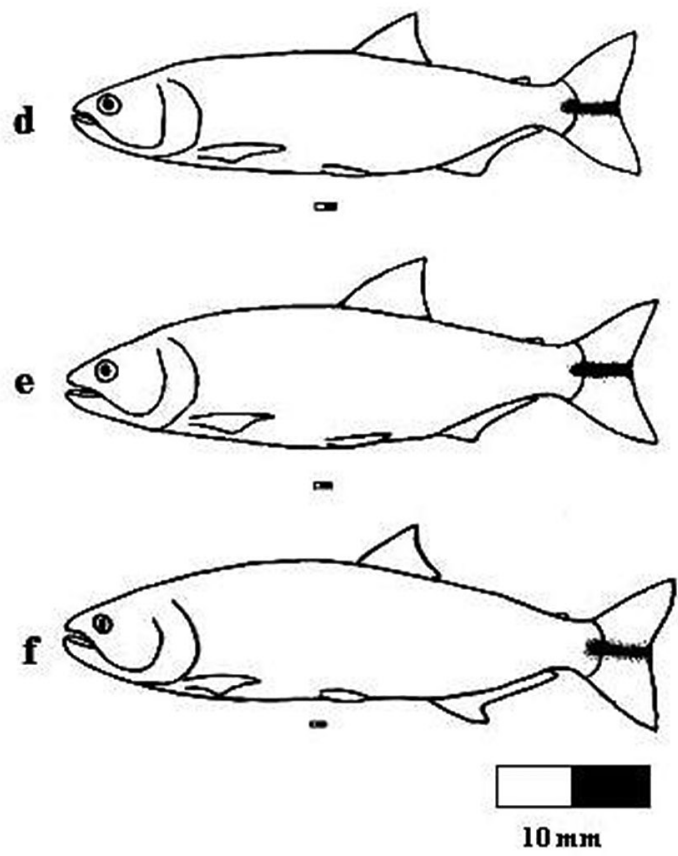

Figure 3. Forms of Salminus hilarii in the different stages of their development. (a) $50-100$; (b) $100-150$; (c) 150 -200; (d) $200+250$; (e) $250+300$; (f) $400+450$.

individuals greater start capacity and maneuvers to move and hunt in an environment full of obstacles besides helping in the escape from predators.

The values for mouth height are directly related to the opening capacity of the mouth, and this opening limiting the size of the prey to be ingested (Werner, 1974). Both the relative height of the mouth is also related to the hydrodynamics of the body (Keast and Webb, 1966; Werner, 1974; Gatz Júnior, 1979a). In fish species with ontogenetic changes, the dimensions of the head and mouth may vary due to ecological characteristics of the environment or within proportional relationships among the body, the head and the jaw, with the biggest ratio in the smaller fish. In $S$. hilarii this differentiation was evident and strongly influenced by an increase in fish length, concomitant to proportional decrease of the head.

In comparisons between head relative length and relative diameter of the eye were noticed a gradual reduction of these values as the fish size increases. This is a common fact in the ontogeny of the later stages of many species of fish (Aleev, 1969). In the larval and juvenile stages freshwater fish tend to stay in the shallow, calm waters, as close to shore or in ponds, where sediments settle out and water transparency increases (Rincon, 1999). In these places the capture of the food can be based on visual orientation in predatory species, with larger eyes and heads being very important. In the process of growth, the fish tend to live in waters that may be deeper or turbid. Thereafter visual guidance can gradually give way in importance to other types of guidance, as the lateral line system and the smell, both in search of food, and in intraspecific communication. Thus it is understandable the gradual reduction in the size of the eye and head. Although a negative allometry in the relative values of the head and eyes is observed, S. hilarii has relatively large head, regardless the size, indicating that it feeds itself on large prey (Gatz Júnior, 1979a; Teixeira and Bennemann, 2007) and the eyes are relatively large and laterally positioned predators typical of fish occupying the middle water (Lincon et al., 1995). Many of the features observed in $S$. hilarii comply with the description given by Webb and Weihs (1986) with a fusiform and tubular body, narrow caudal peduncle, forked fins and efficient propelling surface, coupled with big mouths and powerful jaws are specializations of piscivorous fish.

In our study, we observed that some of the analyzed morphological attributes showed variations along its growth. Morphological variations related to body height, the caudal fin area and dimensions of the head occurred due to allometric changes in own proportional ratios of the fish body structures, which may also indicate adjustments to the conditions of the environments where individuals occupy at various stages of development. On the other hand, others characteristics are not changed indicating the swimming behavior and the lifestyle of the species, keeping a typical morphological pattern of fish with continuous swimming and occupying the middle water, besides piscivorous predatory.

\section{Acknowledgements}

We thank to CAPES for the financial support. I thank also to the friends whose help was very important: André Teixeira da Silva, Leandro Müller Gomiero, Maria M. Aparecida and to the IBAMA for the authorization for fish collections. 


\section{References}

AGOSTINHO, A.A., GOMES, L.C., SUZUKI, H.I. and JULIOJÚNIOR, H.F., 2004. Migratory fishes of Upper Paraná Basin, Brasil. In: J. CAROLSFIELD, B. HARVEY, C. ROSS and A. BAER. Migratory fishes of South América. Washington: Biology, Fisheries, and Conservation Status World Fisheries Trust, pp. 19-98.

ALEEV, Y.G., 1969. Functional and gross morphology in fish. Jerusalem: TT 67-51391. Jerusalem: Israel Progam of Scientific Translations Keter Press.

ANDRADE, D.R., GODINHO, A.L., GODINHO, H.P. and SHIMODA, E., 2004. Biologia reprodutiva da tabarana Salminus hilarii (osteichthyes, characidae) na represa de Três Marias. Revista Brasileira de Ciência Veterinária, vol. 11, no. 3, pp. 123-128. http://dx.doi.org/10.4322/rbcv.2014.359.

BALON, E.K., CRAWFORD S.S. and LELEK, A., 1986. Fish communities of the upper Danube River (Germany, Austria) prior to the new Rhein-Main-Donau connection. Enviromental Biology of Fishes, vol. 154, pp. 242-271.

BREDA, L., FONTES, E. and GOULART, E., 2005. Ecomorfologia de locomoção de peixes com enfoque para espécies neotropicais. Acta Scientiarum Biological Science, vol. 27, no. 4, pp. 371-381.

CARNEIRO, S.C., 2003. Aspectos anatômicos relacionados à natação e à alimentação de nove espécies de peixes characiformes coletados nos Rios Piracicaba e Mogi-Guaçu, Estado de São Paulo. Rio Claro: Universidade Estadual Paulista, 105 p. Tese de Doutorado em Zoologia

CASATTI, L. and CASTRO, R.M.C., 2006. Testing the ecomorphological hypothesis in a headwater riffles fish assemblage of the rio São Francisco, southeastern Brasil. Neotropical Ichthyology, vol. 4, no. 2, pp. 203-214. http://dx.doi.org/10.1590/ S1679-62252006000200006.

CHAO, L.B. and MUSICK, J.A., 1977. A life history, feeding hábitats, and functional morphology of juvenile sciaenid fishes in the York river estuary, Virginia. Fish Bulletin, vol. 75, no. 4, pp. 657-702

GATZ JÚNIOR, A.J., 1979a. Ecological morphology of freshwater stream fishes. Tulane Studies in Zoology and Botany, vol. 21, no. 2, pp. 91-123.

GATZ JÚNIOR, A.J., 1979b. Community organization in fishes as indicated by morphological features. Ecology, vol. 60, no. 4, pp. 711-718. http://dx.doi.org/10.2307/1936608.

GODOY, M.P., 1975. Peixes do Brasil: Subordem Characoidei. Bacia do Rio Mogi Guassu. Piracicaba: Editora Franciscana. vol. 2, pp. 366-377.

GOSLINE, W.A., 1971. Functional morphology and classification of Teleostean fish. Honolulu: University Press of Hawaii. 208 p.

GRAÇA, W.J. and PAVANELLI, C.S., 2007. Peixes da planície de inundação do Alto Rio Paraná e áreas adjacentes. Maringá: EDUEM/Nupélia. 242 p.

HAMMER, Ø., HARPER, D.A.T. and RYAN, P.D., 2001 [viewed 07 July 2015]. PAST: paleontological statistics software package for education and data analysis. Palaeontologia Electronica [online], vol. 4, no. 1, pp. 9. Available from: http://palaeo-electronica. org/2001_1/past/issue1_01.htm.

HONJI, R.M., 2007. Caracterização endócrina durante o ciclo reprodutivo da Tabarana Salminus hilarii (Characiformes: Characidae), em três ambientes distintos: natural, impactado e cativeiro. São Paulo: Universidade de São Paulo, 180 p. Dissertação de Mestrado em Fisiologia.

HONJI, R.M., MELLO, P.H., ARAUJO, B.C. and RODRIGUESFILHO, J.A., 2011. Influence of spawning procedure on gametes fertilization success in Salminus hilarii Valenciennes, 1850 (Teleostei: Characidae): Implications for the conservation of this species. Neotropical Ichthyology, vol. 9, no. 2, pp. 363-370. http:// dx.doi.org/10.1590/S1679-62252011005000012.

JOBLING, M., 1995. Environmental biology of fishes. Dortrecht: Chapman \& Hall. 455 p. Fish and fisheries series.

KEAST, A. and WEBB, D., 1966. Mouth and body form, relative to feeding ecology in the fish fauna of a small lake, Lake Opinicon, Ontario. Journal of the Fisheries Research Board of Canada, vol. 23, no. 12, pp. 1845-1874. http://dx.doi.org/10.1139/f66-175.

LAGLER, K.F., BARDACH, J.E. and MULLER, R.R., 1977. The major groups of fishes. In: K.F. LAGLER, J.E. BARDACH, R.R. MULLER. Ichthyology. 2nd ed. New York: Jonh Wiley \& Sons, pp. 9-52.

LINCON, R.J., BOXSHALL, G.A. and CLARK, P.F., 1995. Diccionario de ecclogia, evolucion Y taxonomia. México: Fondo de Cultura Económica. 488 p.

MOTTA, P.J., CLIFTON, K.B., HERNANDEZ, P. and EGGOLD, B.T., 1995. Ecomorphological correlates in tem species of subtropical seagrass fishes: diet and microhabitat utilization. Environmental Biology of Fishes, vol. 44, no. 1-3, pp. 37-60. http://dx.doi.org/10.1007/BF00005906.

MULLANEY JÚNIOR, M.D. and GALE, L.D., 1996. Ecomorfological relationships in ontogeny: anatomy and diet in gag, Mycteroperca microlepis (Pices: Serranidae). Copeia, vol. 1, no. 1, pp. 167-180. http://dx.doi.org/10.2307/1446952.

NEVES, F.M. and MONTEIRO, L.R., 2003. Body shape size divergence among populations of Poecillia vivipara in coastal lagoons of south-eastern Brazil. Journal of Fish Biology, vol. 63, no. 4, pp. 928-941. http://dx.doi.org/10.1046/j.1095-8649.2003.00199.x.

PAULY, D., 1989. Food consumption by tropical temperate fish populations: some generalizations. Journal Fish Biology, vol. 35, suppl. A, pp. 11-20.

RINCON, P.A., 1999. Uso do micro-habitat em peixes de riachos: métodos e perspectivas. In: E.P. CARAMASCHI, R. MAZZONI and P.R. PERES-NETO. Ecologia de peixes de riacho. Rio de Janeiro: Computer \& Publish Editoração. p. 23-90.

SAMBILAY JÚNIOR, V.C., 1990. Interrelationship between swimming speed, caudal fin aspect ratio and body length of fishes. Fishbyte, vol. 8, no. 3, pp. 16-20.

SHIBATTA, O.A. and GARAVELlO, J.C., 1993. Estudo da variação geográfica em Salminus hilarii, Valenciennes 1849, das bacias do Alto Paraná e São Francisco, através da análise morfométrica multivariada em componentes principais. Naturalia (São José do Rio Preto), vol. 18, pp. 109-116.

SINGER, M.M., 1985. Food habits of juvenile rock-fishes (Sebastes) in a Central California kelp forest. Fish Bulletin, vol. 83, pp. 531-541.

TAKAHASHI, E.L.H., 2006. Ciclo reprodutivo da tabarana, Salminus hilarii (Valenciennes, 1849) (Characidae, Salmininae) na região do baixo rio Sorocaba, SP. Jaboticabal: Universidade Estadual Paulista. 58 p. Dissertação de Mestrado em Aquicultura.

TEIXEIRA, I. and BENNEMANN, S.T., 2007. Ecomorfologia refletindo a dieta dos peixes em um reservatório no sul do Brasil. 
Biota Neotropica, vol. 7, no. 2, pp. 67-76. http://dx.doi.org/10.1590/ S1676-06032007000200007.

VIDELER, J.J., 1993. Fish Swimming. Netherlands: Chapman e Hall. 284 p.

VILLARES JÚNIOR, G.A., GOMIERO, L.M. and GOITEIN, R., 2007. Relação peso-comprimento e fator de condição de Salminus hilarii Valenciennes 1850 (Osteichthyes, Characidae) em um trecho da bacia do rio Sorocaba, Estado de São Paulo, Brasil. Acta Scientiarum Biological Science, vol. 29, no. 4, pp. 407-412.

VILLARES JÚNIOR, G.A., 2014. Ciclo Reprodutivo de Salminus hilarii VALENCIENNES, 1850 (OSTARIOPHYSI, CHARACIDAE) em um rio da região Sudeste do Brasil, SP. Revista Cientifica Vozes dos Vales, vol. 6, no 3.
WEBB, P.W., 1984. Form and function in fish swimming. Scientific American, vol. 251, no. 1, pp. 72-82. http://dx.doi.org/10.1038/ scientificamerican0784-72.

WEBB, P.W. and WEIHS, D., 1986. Functional locomotor morphology of early life history stages of fishes. Transactions of the American Fisheries Society, vol. 115, no. 1, pp. 115-117. http://dx.doi.org/10.1577/1548-8659(1986)115<115:FLMOE $\mathrm{L}>2.0 . \mathrm{CO} ; 2$.

WERNER, E.E., 1974. The fish size, prey size, handing time relation in several sunfishes and some implications. Journal of the Fisheries Research Board of Canada, vol. 30, pp. 787-797.

WINSTON, M.R., 1995. Co-occurrence of morphologically similar species of stream fishes. American Naturalist, vol. 145, no. 4, pp. 527-545. http://dx.doi.org/10.1086/285754. 